Original article

\title{
THE COVID-19 CRISIS MANAGEMENT AS THE MANAGEMENT OF A PROJECT. LESSONS LEARNED IN SPAIN
}

\author{
José Francisco Muñoz-Villalba
}

Engineering and Architecture School, University of Zaragoza, Spain

Received: 20 July 2021

Revised: 15 September 2021

Accepted: 23 October 2021

\begin{abstract}
The COVID-19 crisis has had devastating effects in Spain. One could say that this grave situation has been provoked by its flawed management, considering the harsh reality evidenced by the official figures (total deaths, infections, job losses and other economic data, etc.). Looking at the COVID-19 pandemic on a global scale (Figure 1), it is clear that a wide spectrum of very different actions is required depending on each specific location, and that alternative operation frameworks are needed. If one were to analyse the COVID-19 crisis as a Project, implementing the corresponding Project Management methodologies, many measures would be found that, if applied correctly, would reduce its adverse effects. One of the usual techniques of these methodologies are the lessons learned. This article outlines lessons learned in each of the ten areas of project management knowledge, following the description of any management errors related to each of them. All of this, with the intention of improving crisis management in the future.
\end{abstract}

Keywords: Crisis, COVID-19, lessons learned, project management.

\section{INTRODUCTION}

As of August 2020, Spain was the country with the most COVID-19 infections in Europe. Consequently, it was the country that registered the highest number of deaths as well, a situation that left its health system on the brink of collapse. This scenario motivated twenty prestigious Spanish health specialists to publish in the magazine "The Lancet" an interesting article entitled "The need for an independent evaluation of the COVID-19 response in Spain" (García et al., 2020). In said document, a call was made for an international, independent, and impartial evaluation of the response of the Spanish administrations and health system to the epidemic. Other health specialists (Goodman et al., 2021; Lauder, \& Lightfoot, 2021) wrote in these same lines of argument, all in favour of obtaining an improved set of responses to possible future new outbreaks. It should not go unnoticed that, in June of 2020, Hans Henri P. Kluge, World Health Organization Director for Europe (2020), urged citizenry to prepare for an even deadlier second wave of the virus arriving that fall, and for other epidemics. 


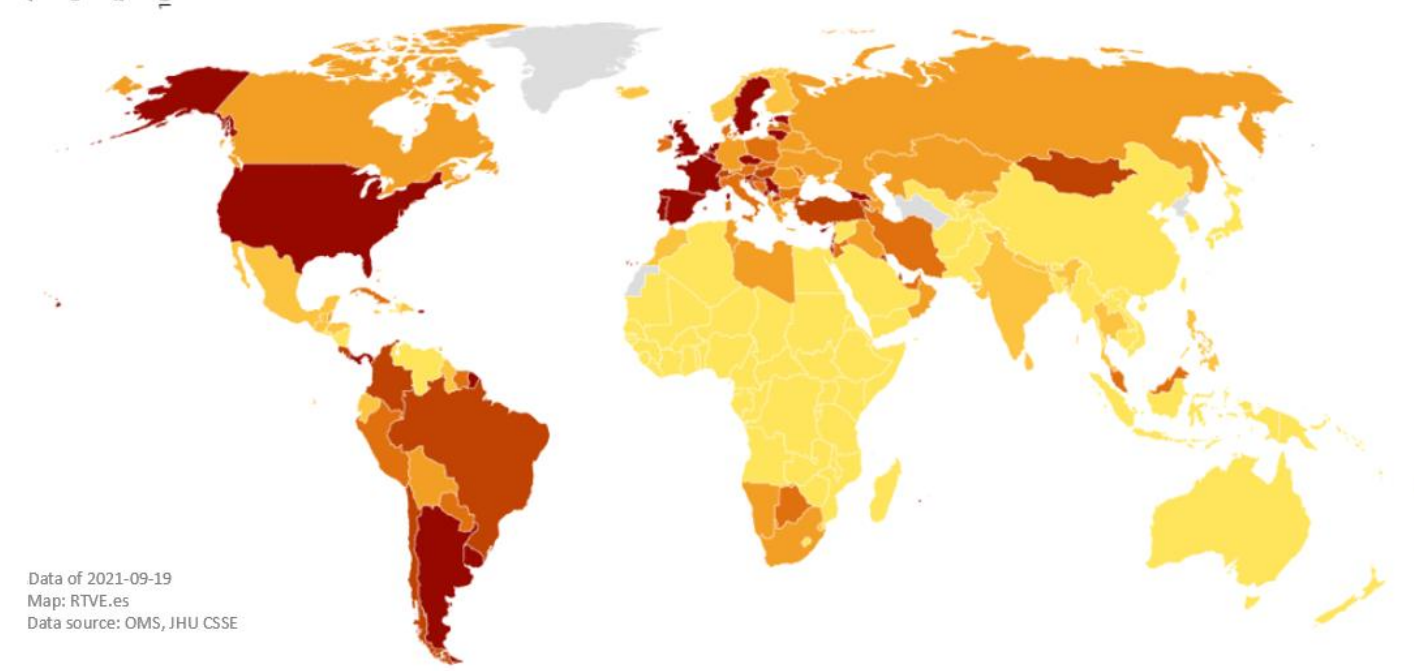

Figure 1: Map of COVID-19 cases in the world

Even though the topic is strongly tied to the medical field, one could also perform an analysis of the COVID-19 crisis from the perspective of Project Management. PMBOK (2017) defines a project as a temporary effort to create a single product of service. The different alarms received towards the end of 2019 from Wuhan (China) define, in terms of the time factor, the start of the project. It will certainly have an end, once the vaccines have reached a large part of the world's population. As for the uniqueness factor, this virus' nature (origin, propagation, virulence, symptoms, health effects, economic repercussions, etc.), as well as mankind's effort to defeat it, is unique in itself.

Furthermore, the PMBOK (2017) defines "Lessons Learned", terminology often used in Project Management, as the knowledge gained from the different events addressed within a project, ultimately improving future performance. What health specialists requested in The Lancet aforementioned article is, in essence, to apply the very definition of Lessons Learned to the COVID19 crisis.

The present work aims to analyse each of the ten areas of Project knowledge set by PMBOK (2017), detecting mistakes made, and extracting lessons learned from each of them, with the intention of assisting government leaders in future decisions. It is not intended to "predict the past", or make political judgements, but rather, to present a technical, objective analysis following the PMBOK (2017) as a script.

\section{LESSONS LEARNED IN PROJECT MANAGEMENT'S AREAS OF KNOWLEDGE}

\subsection{Integration}

Project integration management is a specific task of the Project Manager. However, in the case of this project (the management of the COVID-19 crisis in Spain) it is unclear who performs this task. Is it Pedro Sánchez, the President of the Government of Spain? Is it Salvador Illa, the Minister of Health? Is it Fernando Simón, Director of the Coordinating Centre for Health Alerts and Emergencies? Is it any of the ministers involved in the process, or some military command, perhaps? Each of them has played an important role in the project. Nevertheless, it is as unclear who the Project Manager is, a figure not to be confused with the functional manager or the operations manager. The truth is no person was given the authority to allocate the necessary resources to the project's activities. 
In the case of Spain, the Project Manager may be under the supervision of the President (as functional manager) and should work closely with other relevant "organization managers" (such as government ministers and their teams). The Project Manager does not have to belong to the Government, nor to be a politician, he/she may be an external person who has a temporary leadership role. This project needs an appropriate Project Manager, recognised by the different stakeholder groups, with a holistic view of the crisis and needs to be given the necessary authority to propose measures to the Government of Spain.

\subsection{Scope}

In this COVID-19 crisis in Spain, no one has thus far defined the scope of this project, nor its objectives, and perhaps it is one of the main mistakes made. In addition to not defining it, an uncontrolled expansion of its scope has been allowed without adjustments for time, cost, and resources (knows as "scope corruption"). Scope control is one of the main tasks of the Project Manager, which, as stated before, does not exist as such in the case of Spain.

Related to the previous section, the work of the Project Manager also includes integrating the different objectives of the project. These objectives are undoubtedly tied to each other, listing among them not only saving lives and saving the economy in the face of the COVID-19 crisis, but also responding to COVID-19's conditions for education, tourism, nursing homes, etc. It is only this way that the Project Manager will be able to identify and manage the needs of the different stakeholders to meet said objectives.

Saving lives and saving the economy have been thus far objectives swarmed with controversial responses. "Avoiding the deaths of people with tougher, longer lockdowns" versus "avoiding an economic collapse with smaller, less aggressive lockdowns". It has often been raised as a false dilemma, leading the Government to act aimlessly in one direction or another, ultimately not following a necessary firm and balanced approach, and not learning from the countries that were most successful in managing the crisis.
IESE professor Luis Huete (Expansion, 2020), explains this very well by taking this issue to a two-dimensional matrix (deaths per million inhabitants / estimate of GDP fall). Said matrix is defined by four quadrants: countries that are able to take measures that manage to save lives and save the economy; countries that manage to save lives but are not able to keep the economy afloat; countries that cannot manage to save lives, but seem to be able to keep the economy; and the last quadrant, with countries following measures that are not capable of stopping the deadly effects of the pandemic, nor stopping the fall of its economy.

Another remarkably interesting view of this false dilemma is posed by Richard Baldwin (BBC, 2020), professor of International Economics at the Graduate Institute for International Studies and Development in Geneva, who proposes a double medical and economic curve. Quarantines and containment measures seek to slow the infection rate so that the number of people arriving in hospitals disperses over time (connection between medical shock and economic shock). One cannot let the disease spread without taking containment measures because it would result in a much larger number of people dying without receiving proper treatment. In parallel, the economy needs to be shut down to reduce infection rate. An economic policy is needed to ensure that the economy is being protected by the time the pandemic ends and that people can return to their jobs. Consequently, a containment policy is needed to flatten the epidemic curve and fiscal measures need to be taken to reduce the recession curve.

Ultimately, the necessity for a figure of Project Manager arises, to provide means to manage the scope of the project. It needs to define its scope meticulously, so as to properly administer the different tasks it will involve: consolidate requirements, setting goals, objectives and constraints, as well as integrating the changes to occur during the development of the project. All of the aforementioned, in order for the necessary resources to be allocated accordingly, and for performance to be correctly monitored. 


\subsection{Schedule}

The PMBOK (2017) argues that "the temporal nature of projects implies that a project has a defined beginning and end". There is little discussion as to what the end of the project will be: the accomplishment of having the vaccine applicated to most of the world's population. Contrarily, the start of the project can be discussed extensively.

At the Council of Ministers held on 14th March 2020, the alarm state was decreed in Spain, and on the next day, the citizenry of Spain was confined. In terms of Project Management, this may be the start date of the project for the Government. However, why didn't the project start earlier? Some important dates could have previously marked the start of this project (in reverse chronological order, summarised in Figure 2), and therefore diminished the negative effects of the virus:

- March 13th, 2020: WHO (World Health Organization) points to Europe as the epicentre of the pandemic.

- March 11th: More than 2,000 cases of infections documented, and 47 deaths identified due to COVID-19 in Spain. WHO rates the disease as a pandemic.

- March 9th: Classes are suspended from age 0 to university level.

- March 8th: Mass demonstration for Women's Day in Madrid.

- March 5th: WHO shows concern about the rapid increase in cases in many countries.

- March 4th: The Minister of Labor disseminates a guide for business and workers.

- March 3rd: First death in Spain due to coronavirus.

- March 1st: 86,000 infected and 3,000 people killed worldwide.

- February 26th: First documented local infection in Spain.

- February 22nd: Lombardy and Veneto (Italy) are quarantined.

- February 18th: Putin forbids the entry into Russia of any Chinese citizen.

- February 16th: Flu cases in Madrid and Barcelona increase compared to last year.
- February 15th: First fatality in Europe due to coronavirus (a Chinese tourist in Paris).

- February 14th: A person dies in Valencia due to unknown pneumonia.

- February 13th: Mobile World Congress (Barcelona, Spain) is canceled.

- February 11th: WHO states coronavirus is the world's "number one public enemy."

- February 3rd: China exceeds 700 deaths.

- February 2nd: First deceased outside China.

- January 31st: The first confirmed case of COVID-19 in Spain.

- January 25th: First infection in Europe.

- January 24th: WHO begins to recommend hygiene and social estrangement measures.

- January 23rd: Wuhan (11 million inhabitants), quarantined.

- January 22nd: Minister Salvador Illa says the country is prepared for "any eventuality".

- January 21st: China confirms the route of transmission of the virus is the respiratory tract.

- January 20th: China confirms the virus is transmitted from person to person.

- January 16th: The first case of coronavirus in Europe, tracked to a person in Paris.

- January 11th: China announces the first death due to coronavirus.

- January 1st: WHO asks China for more information on detecting pneumonia cases.

- December 30th, 2019: First warning from a doctor in Wuhan.

- December 25th: 200 admitted to Wuhan's hospitals with breathing difficulty and some of them with coronary damage like those of a heart attack. 


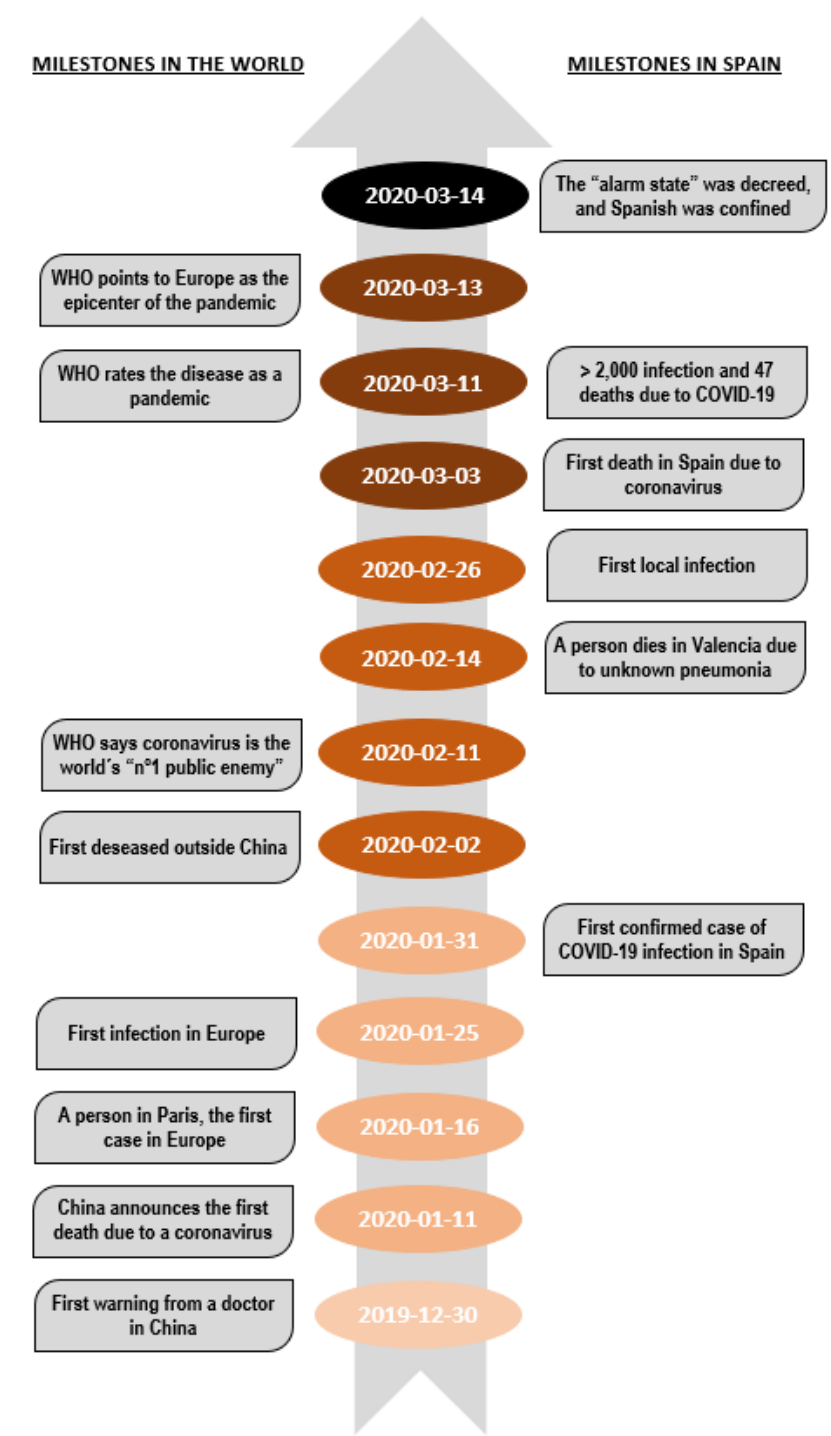

Figure 2: Major milestones in the beginning of the pandemic

One of the consequences of Spain delaying the alarm was that, when the country entered the slowdown phase of the epidemic (after a month and a half of the health crisis beginning), more than 15,000 deaths had already been reported, and 152,000 cases of infection had been exceeded. Another fact in the same vein: when the virus had barely entered Spain, Italy was already taking drastic measures never seen before in Europe after detecting several active hotspots.

In Spain, this delay in considering the beginning of the project resulted in its schedule being non-existent from the start. For this reason, the status of the project could not be monitored, nor the conditions that the continuous changes had on the project deadlines (e.g., improvisation of successive extensions of lockdown).

\subsection{Costs}

In the project at hand, it is exceedingly difficult to close a budget, especially since there are numerous variables involved, as explained in the integration section. So much so that it is surprising that a proper effort to perform a budgetary planning was evaded for so long.

According to a study by Funcas (Savings Banks Foundation), the upturn of the Spanish economy in 2021 will remain at $6.3 \%$ while the drop in 2020 exceeded $11 \%$. In other words, the crisis will probably last longer than the Government expected, and it will be more difficult to return to the starting point. 
In this regard, an explanation could be found in the policies the Spanish Government followed during the beginning of the crisis, opposite to what most European countries were implementing: lengthening ERTEs (Temporary Employment Regulation Files)
(elEconomista.es, 2020), lowering taxes, ... It was not until much later that the Spanish Government reconsidered the possibility of extending the ERTEs. The effect of COVID19 on Spain's labour market is shown in Figure 3.

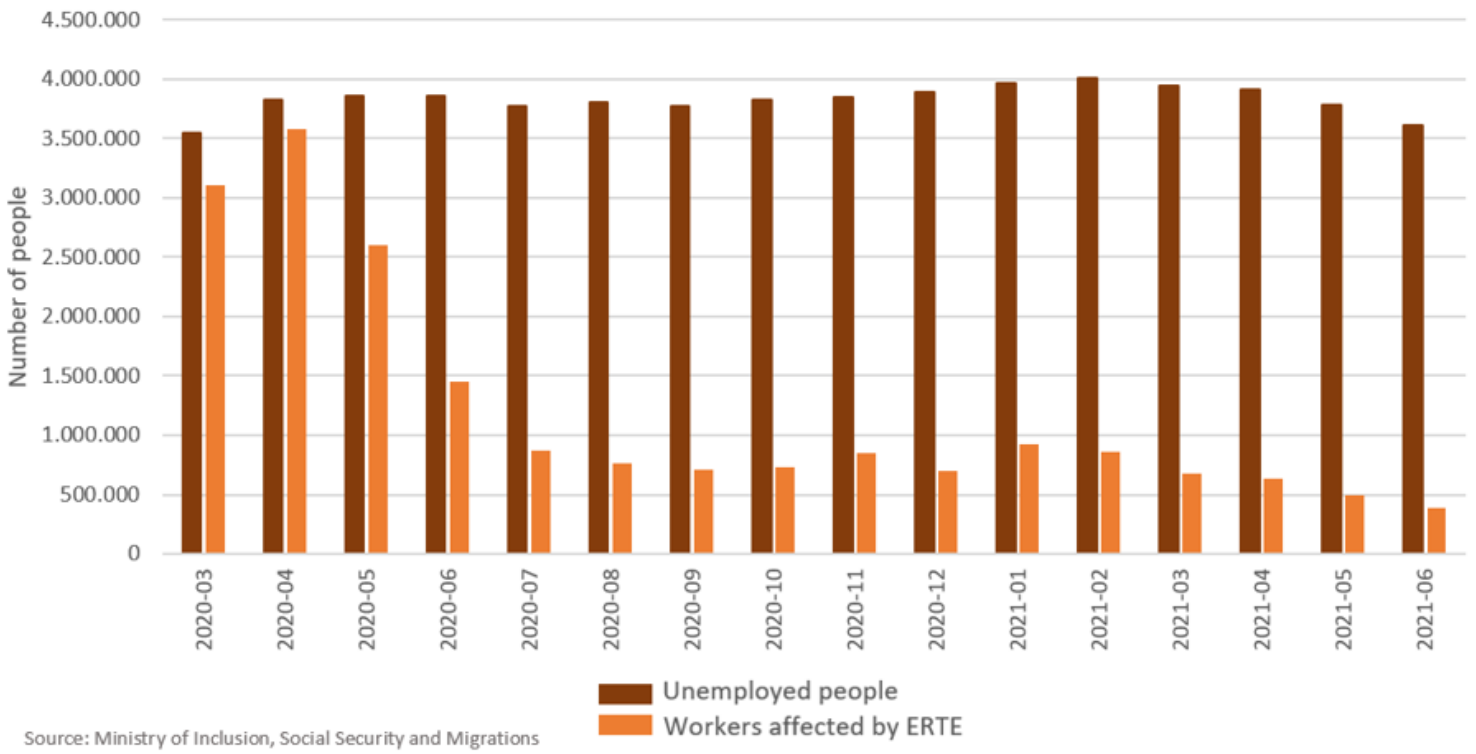

Figure 3: Data on the labour market in Spain

One important aspect is even recognised by the British press, where they recognise the "magnificent primary care system" of the Spanish Health Service. All of this, while pointing to the "years of austerity" experienced by hospitals in the last decade (one of the sectors most affected by budget cuts) as the main reason why the Spanish hospitals overflowed over several weeks (laSexta, 2020).

\subsection{Quality}

The number of COVID-19 deaths has been one of the main metrics used in the last year. Nevertheless, these metrics have not followed the same criteria in all countries. Modig et al. (2021) argued that current available information makes it difficult to assess with certainty its exact value.

Since the beginning of the crisis, official statistics from the Ministry of Health showed only the deceased who were tested for the coronavirus and tested positive. In spite of this criteria, the number of deaths, compared to previous years, was suspected to be much greater. For this reason, it could be concluded from the data of the Instituto Nacional de Estadística (INE, National Statistical Institute, 2020) that there are 16,000 more deceased by COVID-19 than those of the Ministry of Health data, which as of May 21st 2020 counted 27,940 (Centro Nacional de Epidemiología, 2020). On the other hand, WHO raised the Ministry of Health's figure by 3,000 and the daily mortality monitoring system (MoMo, 2020) still estimated 5,000 deaths more than those reported by the INE. In addition, when the Government of Spain changed the counting criteria, it still reduced (at the end of May 2020) in 2,000 people the number of deaths by COVID-19. National mourning has been tarnished by confusion in the statistics and changing the pandemic data at the last minute creates credibility problems in crisis management. In January 2021, the difference is even greater $(80,202$ deaths according to the INE, while the Ministry of Health recognises 50,837 deaths due to COVID-19). The official figures are shown in Figure 4. 


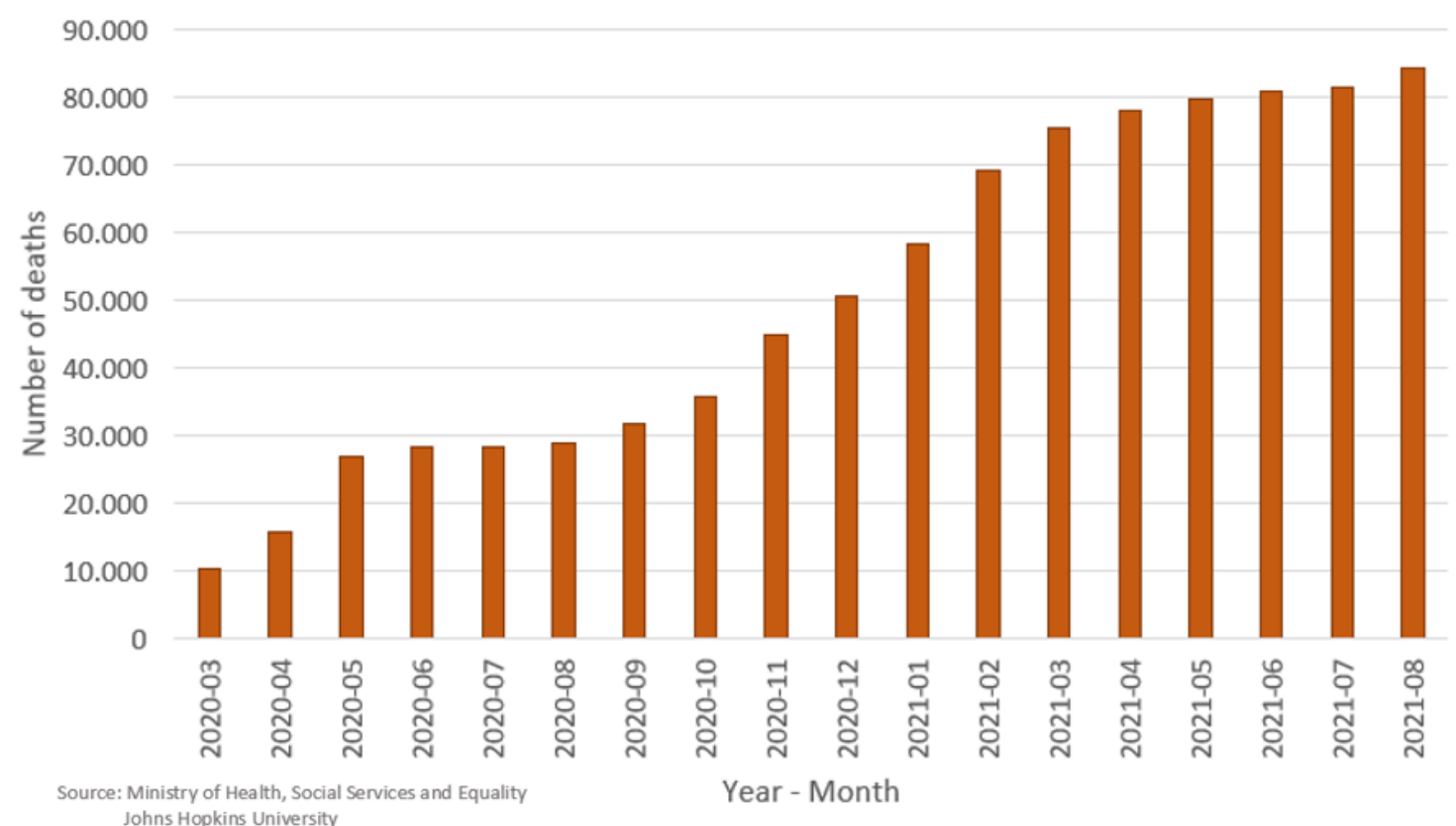

Figure 4: Data on accumulated deaths due to COVID-19 in Spain

Other European countries revised their metrics to adapt to reality (such as France and the United Kingdom, which added to their number of deceased those who occurred in nursing homes, even if they had not been tested). Work metrics are used as the basis for developing test scenarios for the project, as risk exposure margins, and as a basis for improvement initiatives. For these reasons it is especially important to define them appropriately.

\subsection{Resources}

Seeking an equivalence between the Government of Spain (with a President, 22 Ministries and 30 State Secretariats) and the types of organizations defined by the PMBOK (2017), it can be said that the Government has a functional organization, since it has an organizational structure in which staff are grouped by areas of specialization and with functional managers (the Ministers). In the design of COVID-19 crisis management in Spain as a project, a matrix structure should be thought of, in which the Project Manager would share responsibilities with the Ministers to prioritise and direct the work of the people assigned to the project team (some political positions, high-level public officials in areas such as health or economics, military office, recognised independent professionals, and anyone considered by the Project Manager).

Unclear as the Project Manager figure may be in this case, there are many identified members of the project team, with responsibilities inherent to their political offices and public officials. However, there is no clearly defined official project team.

A mistake related to resources and communications is the "committee of experts". At the beginning of May 2020, the President announced the creation of a "technical committee for de-escalation", a team of scientists from various fields who were to design the de-escalation plans. Ultimately, the Government admitted there was no expert committee responsible for assessing the health situation and deciding on the de-escalation process of the lockdown according to the territories. Nevertheless, there was a group of fourteen civil servants from the Ministry of Health, and an external epidemiologist advising the Government.

\subsection{Communications}

Communications management seeks to ensure that the information needs of the project and its stakeholders are met by the implementation of activities that lead to the effective exchange of information. 
In this case there were several signs of improvisation in communications:

- Written formal communication: Royal Decree 463/2020 was approved at the last minute of the previous day, entering into force at the same time of its publication, giving no time to any reaction in many cases.

- Informal written communication: filtration of drafts through social networks of the previously cited Royal Decree, which increased confusion among the population.

- Oral formal communication: daily press conferences on the status of COVID-19 were arranged in Spain where different people would show each day, especially in the first weeks of the crisis (the President of the Government, VicePresidents and several ministers, military commanders, director of the Coordinating Centre for Health Alerts and Emergencies, etc.) With their messages not always aligning with each other, bewilderment and distrust began increasing among the population.

- Informal oral communication: interviews in various media with civil servants on technical issues (health, economic) that resulted in political responses.

- Changes in the message by shifting from oral to written communication. On November 2020 the President of the Government announced a "Complete Vaccination Plan" in Spain, which was ratified by the Minister of Health a few days later as "State Plan for Vaccination COVID-19". From that moment, there was no more words about a plan, and the document published by the Government was "Vaccination Strategy COVID-19 in Spain. Guidelines". In this case, the Government confused the concepts and contents of a "Plan" and a "Strategy".

Therefore, it is necessary to develop an appropriate communication strategy, based on the needs of the project (e.g., laws and other rules) and stakeholders (e.g., press conferences of those responsible) to, from that strategy, develop a communications management plan that answers questions such as: what is to be communicated? Who has to communicate it? All the above focused on:

- Defining and controlling the flow of information.

- Involving all stakeholders: Within the special situation we are living because of this crisis.

- Avoiding rumours and hoaxes, and issue useful and essential information, with specific, clear messages.

- Establishing a continuous flow of information with the most critical sectors, among other reasons, to reduce the tension.

\subsection{Risks}

One of the earliest, widely publicly discussed risks this project had was the holding of demonstrations for Women's Day (March 8th, 2020) in several Spanish cities. There had already been several caveats in previous days. The European Union Agency for Disease Control and Prevention (ECDC) had called to avoid "mass acts" and to prevent "unnecessary mass concentrations" due to coronavirus, on March $2^{\text {nd }}$. The Health Alert Coordination Centre (CCAES) was aware, on March $6^{\text {th }}$, that the spread distance of the virus was "up to two meters" and that there was a large percentage of COVID-19 infected that were asymptomatic. A report by the Civil Guard Corps concluded that from March $5^{\text {th }}$ no demonstration or concentration were to be held in Madrid. However, the Ministry of Health had banned an evangelical congress in Madrid a few days earlier (much less numerous in terms of attendees). The difference in criteria when rating the risks in one case and the other was unfathomable. If the probability and impact of potential infections had been technically assessed, the 8-M demonstrations, or any other type of mass gathering (including sporting events) would not have been allowed. 
Another error in the assessment of risk occurrence probability came from the Director of the Health Alerts and Emergencies Coordination Centre, who, on March $24^{\text {th }}$, 2020, stated that "There is no reason to be alarmed by the coronavirus" (de Aragón, 2020). Far from learning from his own mistake, on January $11^{\text {th }}, 2021$, he stated the following about the British strain of the virus: "The variant, if it has any impact, it will be marginal in our country". After a few days, the grim reality was the British strain increased by 70 percent the number of infections.

As a result of not acting on time, the effect was lethal to the spread of the disease, and Spain climbed to the top of statistics tables of deceased and infected.

Risk management should be planned to ensure that the level, type, and visibility of the risk response are proportional to both risk and project importance to all stakeholders, and it should be initiated as soon as the project is conceived.

\subsection{Procurements}

An example of an error in the purchases of the Government of Spain was, at the beginning of the crisis that of 659,000 rapid tests for the diagnosis of coronavirus to a Chinese company, through a Spanish company specialised in cosmetics. Their reliability should exceed $80 \%$ and the reality showed that it was $30 \%$ at a cost of more than 17 million euros (El País, 2020). It seems that in the purchase process, there were people involved that did not bring any advantage and, in addition, the product purchased did not respond to the needs.

Another example was the contracting by the Centre for Sociological Research of a survey on the management of the Government with COVID-19, worth 90,000 euros, to a company related to the political party to which the President of the Government belongs. A contract with no public tender nor a prior announcement.

In neither case does the urgency justify irregularities in the procurement. Purchases of sanitary material must be made from clear specifications, with contracts clearly establishing deliverables and expected results, including any transfer of knowledge from seller to buyer.

\subsection{Stakeholders}

One of the most important stakeholder groups (at least the ones that have suffered the most physical and mental pain) has been those with health issues due to coronavirus. The Second Vice-President of the Government said four years ago "We must politicise pain. Let it become proposals to change reality". Surely when he uttered these words, he did not imagine that four years later he would have important government responsibilities in a situation of a serious health crisis is that of COVID-19. But what are the expectations of coronavirus sufferers, or relatives of the deceased? Pain should be put into medical care, psychological care, even palliative care in certain cases, which is what those affected expect. What they do not expect is for someone to politicise their pain. It is a consideration that also relates to other areas of knowledge of project management such as communications.

Another group of stakeholders to highlight, in terms of prominence, has been the healthcare collective. A collective who is working to the point of exhaustion, in the front line of fire, sometimes without the right means, and with the only recognition of spontaneous applause from the windows of our houses at $8 \mathrm{pm}$ during the period of lockdown, and a few words of thanks from the President of the Government. More health workers are needed in Spain, and better compensated. It is a consideration which also relates to other areas of knowledge of project management such as resources.

Further stakeholder cases could be widely discussed: the education collective (the return to school safely), the tourism sector (which is key because of the wealth it contributes to the Spanish economy), workers who have lost their jobs due to the economic crisis associated with the health crisis, shows and cultural activities of all kinds (theatres, concerts, cinemas, etc.), sporting events (both sports and public), hospitality industry, retail, 
etc. The list is long, but it can be defined and analysed.

This project needs an identification of Spanish and international individuals, groups or organizations (such as European Union or WHO) that may affect or be affected by it. Analysing their expectations and impact on the project and developing appropriate management strategies is invaluable to achieve effective stakeholder participation in the decisions and implementation of the project.

\section{CONCLUSIONS}

"We have come out, and we have come out stronger" said the President of the Spanish Government, on May 23, 2020, about the COVID-19 crisis in Spain. However, more than one year and a half later, the statement is still questionable among Spanish citizens. What are we better off at than before the coronavirus? Eighty-four thousand deaths later (official figure of the Spanish Ministry of Health), one hundred thousand more unemployed (official figure of the Spanish Ministry of Work and Social Economy) than before the crisis, doctors and other health workers exhausted, and other figures such as these raise many doubts towards the words of the President. That is why it is important to set political ideas aside and treat the crisis with technical criteria and learning from mistakes, to plan actions, instead of improvising.

This article highlights some mistakes in the management of the COVID-19 crisis in Spain, and the lessons learned from each of these ten areas of knowledge (integration, scope, time, cost, quality, human resource, communications, risks, procurement, and stakeholders). Different examples are shown below:

- A good, combined management of schedules and risks could have brought forward containment, thus reducing the effects of the first wave of the pandemic.

- A correct definition of metrics and a good communication strategy can increase public confidence.

- In the human resources area, the Project Manager, independent, both leader and manager of the project group, must form an efficient highlevel project team by asking Ministers for internal human resources (mainly public officials) and completing it with the necessary external resources (independent professionals, mainly).

Considering the crisis management of COVID-19 as the management of a Project, the contribution of this paper is to demonstrate that the use of Project Management methodologies can be of great help in crisis management such as this one. It also demonstrates the importance of learning from what happened and to be prepared in order to implement appropriate actions in the event of new waves of COVID-19 infections, the emergence of new mutations of the virus, or new phases within the project (such as the vaccination of the world's population).

\section{REFERENCES}

Baldwin R., BBC (2020). Qué es la "doble curva" y por qué es un "falso dilema" elegir entre salvar vidas o salvar la economía. $\quad 7 \quad$ April. https://www.bbc.com/mundo/noticias52158532. (Accessed August 2020).

Centro Nacional de Epidemiología. (2021). https://cnecovid.isciii.es/covid19/.

(Accessed June 2020 and February 2021).

elEconomista.es. (2020). Los países europeos bajan impuestos y alargan los ERTE para evitar recaídas en la economía. https://www.eleconomista.es/economia/n oticias/10617965/06/20/El-Covid19pasa-ya-una-factura-de-57000-millonesde-euros-al-gasto-publico.html. (Accessed August 2020).

El País. (2020). Los test rápidos de coronavirus comprados en China no funcionan bien. https://elpais.com/sociedad/2020-0325/los-test-rapidos-de-coronaviruscomprados-en-china-no-funcionan.html. Accessed August 2020.

Funcas. (2021). El Panel de Funcas espera que el PIB crezca este año un $6,3 \%$ tras caer el $11,2 \%$ en 2020. 20 Jan, 2021. https://www.funcas.es/prensa/el-panel- 
de-funcas-espera-que-el-pib-crezca-esteano-un-63-tras-caer-el-112-en-2020/. (Accessed February 2021).

García, A., Alvarez, C., Arenas, A., Bengoa, R., Borrell, C., Del Val, M., Franco, M., Gea. M., Gestal, J., González, B., Hernández, I., March, J., Martín, J., Menéndez, C., Minué, S., Muntaner, C., Porta, M., Prieto, D., Vives, C., \& Legido, H. (2020). The need for an independent evaluation of the COVID19 response in Spain. The Lancet, 396, 529-530. https://doi.org/10.1016/S01406736(20)31713-X

Goodman, J. et al. (2020). UK COVID-19 public inquiry needed to learn lessons and save lives. The Lancet, 397: 177180. https://doi.org/10.1016/S01406736(20)32726-4

de Aragón, H. (2020). Fernando Simón: "No hay razón para alarmarse con el coronavirus".

https://www.heraldo.es/noticias/sociedad /2020/02/09/fernando-simon-no-hayrazon-para-alarmarse-con-elcoronavirus-1357827.html. Accessed August 2020.

Huete L., Expansion (2020). ¿Salvar vidas o salvar la economía? Un falso dilema. 21 May,

https://www.expansion.com/economia/2 $\underline{020 / 05 / 21 / 5 e c 5 a e 5 a e 5 f d e a 114 d 8 b 45 f 2 . h}$ tml (Accessed August 2020).

Instituto Nacional de Estadística. (2021). Estimación del número de defunciones semanales durante el brote de covid-19. https://www.ine.es/experimental/defunci ones/experimental defunciones.htm. (Accessed June 2020 and February 2021).

laSexta (2020a). Enfermos hacinados y sin guardar la distancia de seguridad en hospitales de Madrid. https://www.lasexta.com/noticias/nacion al/enfermos-hacinados-y-sin-guardar-ladistancia-de-seguridad-la-saturacion-delas-urgencias-del-hospital-12-deoctubre_202003255e7b625695e62a0001 b9f9c7.html. (Accessed August 2020).
Lauder, M., \& Lightfoot, N. (2021). Learning from crisis. The Lancet, Online First, 2021-02-24

https://doi.org/10.1016/S01406736(21)00376-7

Ministerio de

Sanidad. https://www.mscbs.gob.es/profesionales/ saludPublica/ccayes/alertasActual/nCov/ documentos/Actualizacion_315_COVID -19.pdf (Accessed February 2021).

Ministerio de Trabajo y Economía Social https://prensa.mites.gob.es/WebPrensa/n oticias/laboral/detalle/3940 (Accessed February 2021).

Modig, K., Lambe, M., Ahlbom, A., \& Ebeling, M. (2021). Excess mortality for men and women above age 70 according to level of care during the first wave of COVID-19 pandemic in Sweden: A population-based study. The Lancet, Regional Health Europe. Research paper, 4, May 01, 2021. https://doi.org/10.1016/j.lanepe.2021.10 $\underline{0072}$

MoMo. (2021). Mortalidad por todas las causas. España. https://momo.isciii.es/public/momo/dash board/momo dashboard.html. (Accessed June 2020 and February 2021).

PMBOK. (2017). A guide to the project management body of knowledge. Sixth Edition. Newton Square. Pennsylvania. Project Management Institute. ISBN 978-1-62825-184-5.

Presidencia del Gobierno. (2020). https://www.lamoncloa.gob.es/presidente/i ntervenciones/Paginas/2020/2305.aspx?qfr $=23$. (Accessed August 2020).

World Health Organization. (2020). Statement - Preparing for the autumn is a priority now at the WHO Regional Office for Europe.

https://www.euro.who.int/en/mediacentre/sections/statements/2020/stateme nt-preparing-for-the-autumn-is-apriority-now-at-the-who-regional-officefor-europe (Accessed August 2020). 